\title{
Rice bran as a substitute for soy protein and erythorbate in chicken nuggets
}

\section{Farelo de arroz como substituto de proteína de soja e eritorbato em nuggets de frango}

\author{
Ruth dos Santos da Veiga ${ }^{1}$; Daneysa Lahis Kalschne ${ }^{2}$; Rosana Aparecida da Silva- \\ Buzanello ${ }^{3}$; Éder Lisandro de Moraes Flores ${ }^{4}$; Marinês Paula Corso ${ }^{3}$; \\ Cristiane Canan ${ }^{3 *}$
}

\begin{abstract}
Highlights:
Defatted rice bran is an interesting substitute of allergenic meat products additive.

The soy protein can be replaced by defatted rice bran in chicken nuggets.

Rice bran presents antioxidant activity comparable to sodium erythorbate.

Chicken nuggets added of defatted rice bran are sensory accepted.
\end{abstract}

\begin{abstract}
Rice bran is a byproduct with high biological value protein, fiber and phytic acid content. The nutritional and technological properties of rice bran have been highlighted and are attractive for food application. This research aimed at replacing soy protein (SP) and sodium erythorbate (SE) by defatted rice bran (DRB) in chicken nuggets. Three formulations were prepared: T1 with SP and SE; T2 with SP and without SE; and T3 with total SP and SE replacement by DRB. Lipid stability was evaluated by thiobarbituric acid reactive substances (TBARS) on storage days 0,30 , and $60\left(-18^{\circ} \mathrm{C}\right)$. Physicochemical and microbiological parameters were also evaluated. Color, aroma, flavor, texture acceptance, and overall impression was evaluated using a 9-point hedonic scale for 60 days of storage. T3 presented lipid stability comparable to $\mathrm{T} 1 \mathrm{in}$ all intervals evaluated reinforcing the antioxidant potential of DRB. However, T2 showed the lowest lipid stability due to the absence of antioxidants, presenting rancid aroma and flavor not allowing for its sensorial evaluation. Physico-chemical and microbiological parameters were either not influenced or positively influenced by DRB addition. For all attributes, T3 and $\mathrm{T} 1$ presented similar acceptance sensory means, with $>72.4 \%$ acceptability index. DRB is a rice byproduct potentially suitable for its use by the meat industry.
\end{abstract}

Key words: Antioxidant. Byproduct. Lipid peroxidation. Meat product. Sensory acceptance. Thiobarbituric acid reactive substances.

\footnotetext{
1 Discente do Curso de Mestrado em Tecnologia de Alimentos, Universidade Tecnológica Federal do Paraná, UTFPR, Medianeira, PR, Brasil. E-mail: ruth.stos@hotmail.com

2 Pós-Doutorado, Programa de Pós-Graduação em Tecnologia de Alimentos, UTFPR, Medianeira, PR, Brasil. E-mail: daneysa@ htomail.com

3 Prof ${ }^{\text {as }}$, Dr ${ }^{\text {as }}$, Departamento Acadêmico de Alimentos, UTFPR, Medianeira, PR, Brasil. E-mail: rbuzanello@utfpr.edu.br; corso@ utfpr.edu.br, canan@utfpr.edu.br

4 Prof. Dr., Departamento Acadêmico de Química, UTFPR, Medianeira, PR, Brasil. E-mail: eder@utfpr.edu.br

* Author for correspndece
} 


\section{Resumo}

O farelo de arroz é um subproduto que contém proteína de alto valor biológico, fibra e ácido fítico. As propriedades nutricionais e tecnológicas do farelo de arroz têm sido destacadas e se mostrado vantajosas para a aplicação em alimentos. O objetivo desta pesquisa foi substituir a proteína de soja (SP) e o eritorbato de sódio (SE) por farelo de arroz desengordurado (DRB) em nuggets de frango. Três formulações foram preparadas: T1 com SP e SE; T2 com SP e sem SE; e T3 com substituição total de SP e SE por DRB. A estabilidade lipídica foi avaliada por substâncias reativas ao ácido tiobarbitúrico aos 0 , 30 e 60 dias de armazenamento $\left(-18^{\circ} \mathrm{C}\right)$. Os parâmetros físico-químicos e microbiológicos, e a aceitação também foram analisados. $\mathrm{Na}$ análise sensorial, os atributos de cor, aroma, sabor, textura e impressão global foram avaliados usando-se a escala hedônica de 9 pontos após 60 dias de armazenamento. $\mathrm{O}$ T3 apresentou estabilidade lipídica comparável ao T1 em todos os intervalos analisados reforçando o potencial antioxidante do DRB. Entretanto, T2 apresentou menor estabilidade lipídica devido à ausência de antioxidantes, apresentando aroma e sabor de ranço que não permitiram sua avaliação sensorial. Os parâmetros físico-químicos e microbiológicos não foram influenciados, ou foram positivamente influenciados pela adição de DRB. Para todos os atributos, T3 e T1 apresentaram médias sensoriais de aceitação semelhantes, com índice de aceitabilidade superior a 72,4\%. O DRB é um subproduto do arroz com potencial para ser usado pela indústria da carne.

Palavras-chave: Antioxidante. Subproduto. Oxidação lipídica. Produto cárneo. Aceitação sensorial. Substâncias reativas ao ácido tiobarbitúrico.

\section{Introduction}

Rice bran is obtained during rice grain processing, representing approximately $10 \%$ of the total grain weight (Gul, Yousuf, Singh, Preeti, \& Wani, 2015). It possesses excellent nutritional quality as it is originated from grain pericarp, with large protein, fiber, lipids, vitamins, and minerals contents (Pestana, Mendonça, \& Zambiázi, 2008). It is an excellent source of phytochemicals and antioxidative compounds such as phytic acid (Canan et al., 2012), oryzanols (Akihisa et al., 2000), tocotrienols, tocopherols (Jariwalla, 2001), phytosterols, squalene, polycosanols, ferulic acid, and inositol (Chotimarkorn, Benjakul, \& Silalai, 2008).

The proteins found in rice bran (about 15\%) have been studied by a number of researchers, due to their suitable nutritional quality and high biological value, adequate amino acid composition to human metabolism (Han, Chee, \& Cho, 2015), and digestibility higher than 90\% (Zhang, Zhang, Wang, \& Guo, 2012; Han et al., 2015). Studies have reported their hypoallergenic characteristics
(Wang, Hettiarachchy, Qi, Burks, \& Siebenmogen, 1999), hypocholesterolemic (Chrastil, 1992), anticancer (Shoji et al., 2001) and antioxidant activity (Chanput, Theerakulkait, \& Nakai, 2009; Thanonkaewa, Wongyai, Mcclements, \& Decker, 2012; Goufo \& Trindade, 2014).

Rice bran dietary fiber content reaches nearly $27 \%$ and it has been correlated with positive effects, such as laxative and cholesterol-lowering abilities. Rice bran contains many biological active polysaccharides with excellent physiological properties that could improve health and prevent diseases - working as an anti-tumor and immune function (Takeshita et al., 1992; Tzianabos, 2000). The effects of soluble and insoluble rice bran fiber in the fasting and postprandial reduced glucose levels were confirmed by C. R. Silva, Oliveira, Souza and Silva (2005). Rice bran when applied to food products improves texture, gelation, emulsification, and stabilization of foods (Zheng, Nisi, Wu, \& Yin, 2019). The increased demand for rice bran oil as a functional food ingredient has led to an increase of defatted rice bran supply obtained 
after oil extraction. It is considered a rice processing secondary byproduct and often discarded or used as animal feed (Chan, Khong, Iqbal, \& Ismail, 2013).

On the other hand, oxidation and auto-oxidation of lipids are one of the major causes of quality deterioration and reduced meat products' shelf life. The oxidative process could alter meat quality parameters such as color, flavor, aroma, texture and even its nutritional value (Basanta et al., 2018; Estévez, \& Lorenzo 2019). Mincing, cooking, like other meat processing methods disrupt muscle cell membranes. This process allows for the interaction of unsaturated lipids with pro-oxidant such as nonheme iron, accelerating lipid oxidation and leading to rapid quality deterioration and development of rancidity, especially prior to refrigerated storage (Shimokomaki, 2006). The use of antioxidants could prevent undesirable oxidative effects preserving meat and meat products' quality and stability during their shelf life (Olivo, 2006).

The addition of soy proteins, currently classified as food allergen (Ebisawa, Ito, \& Fujisawa, 2017), into meat products is carried out due to its functional properties and low cost (Piccolo et al., 2016). Its addition to meat products could lead to health problems in individuals allergic to these proteins. Thus, alternative ingredients ought to be studied, especially rice bran, which besides its low cost it possess a high antioxidant potential (Zheng et al., 2019). Taking into account the various health benefits associated with rice bran consumption and its antioxidant potential, it could be used as raw material for the development of food products improved quality (Gul et al., 2015; Nandi \& Ghosh, 2015). Additionally, rice bran possesses distinctive functional properties that could improve meat products quality. Thus, this study aimed at evaluating the replacement of soy protein by defatted rice bran in chicken nuggets. The antioxidant potential of rice bran in chicken nuggets was compared to sodium erythorbate, and physico-chemical and microbiological quality, and sensory acceptance were determined.

\section{Material and Methods}

\section{Chicken nuggets preparation}

The pellet-form defatted rice bran (DRB) was provided by Riograndense de Óleos Vegetais Company (Irgovel, Pelotas-RS, Brazil), and previously ground in a Wiley mill (Solab, SL 31, Piracicaba-SP, Brazil) with a 70 mesh mean particle size, packed in plastic bags and frozen at $-20{ }^{\circ} \mathrm{C}$. Thigh and boneless drumstick, mechanically separated meat and abdominal chicken fat used as raw materials were provided by the Industrial Poultry Unit in Western Paraná. They arrived frozen and were kept under freezing $\left(-20 \pm 1{ }^{\circ} \mathrm{C}\right)$ until the nuggets preparation.

Three chicken nuggets formulations ( $2 \mathrm{~kg}$ each) were prepared (Table 1) as described below:

Treatment 1 (T1): added with soy protein and sodium erythorbate as an antioxidant, considered the standard one;

Treatment 2 (T2): added with soy protein, without sodium erythorbate;

Treatment 3 (T3) added with DRB and without both soy protein and sodium erythorbate.

The frozen chicken was minced and meat emulsions were prepared using a cutter (MTK 661 model, Mado, Germany). The emulsions were comprised of abdominal fat, mechanically separated chicken meat, ice and soy protein or rice bran. The minced meat in conjunction with salt, and sodium tripolyphosphate were blended for one minutein cutter. The condiments were slowly added during a further two and a half minutes of blending. The final temperature was between 10 and $12{ }^{\circ} \mathrm{C}$. Subsequently, the resulting mass was placed on polyethylene recipients and covered with a polyethylene film and stored for $24 \mathrm{~h}$ in a freezer $\left(-20 \pm 2{ }^{\circ} \mathrm{C}\right)$. The frozen mass was cut into pieces ( $2.25 \mathrm{~cm}$ long and $2 \mathrm{~cm}$ wide), breaded and frozen $\left(-20 \pm 2{ }^{\circ} \mathrm{C}\right)$. The frozen nuggets were kept at $4 \pm 2$ ${ }^{\circ} \mathrm{C}$ for $3 \mathrm{~h}$ before pre-frying in soybean oil for one min at $180 \pm 1^{\circ} \mathrm{C}$. The chicken nuggets were stored in polyethylene wrappers at $-20 \pm 2{ }^{\circ} \mathrm{C}$ for 60 days. 


\section{Chicken nuggets formulations}

\begin{tabular}{|c|c|c|c|c|}
\hline & Raw material and ingredientes & $\mathrm{T} 1(\%)$ & $\mathrm{T} 2(\%)$ & $\mathrm{T} 3(\%)$ \\
\hline \multirow{9}{*}{ Mass } & Minced thigh and drumstick boneless & 50.00 & 50.25 & 50.25 \\
\hline & Salt (Moc) & 1.60 & 1.60 & 1.60 \\
\hline & Sodium erythorbate (Ibrac) & 0.25 & - & - \\
\hline & Sodium tripolyphosphate (Ibrac) & 0.25 & 0.25 & 0.25 \\
\hline & Monosodium glutamate (Ajinomoto) & 0.05 & 0.05 & 0.05 \\
\hline & Dehydrated garlic (Geriba) & 0.15 & 0.15 & 0.15 \\
\hline & Green seasoning (Geriba) & 0.10 & 0.10 & 0.10 \\
\hline & White pepper (Geriba) & 0.05 & 0.05 & 0.05 \\
\hline & Dehydrated onion (Geriba) & 0.05 & 0.05 & 0.05 \\
\hline \multirow{5}{*}{ Emulsion } & Abdominal fat of chicken & 4.75 & 4.75 & 4.75 \\
\hline & Mechanically separated meat & 23.75 & 23.75 & 23.75 \\
\hline & Crushed ice & 14.25 & 14.25 & 14.25 \\
\hline & Concentrated soy protein (Ibrac) & 4.75 & 4.75 & - \\
\hline & Defatted rice bran (Irgovel) & - & - & 4.75 \\
\hline
\end{tabular}

T1: chicken nuggets added of soy protein and sodium erythorbate; T2: chicken nuggets added of soy protein without sodium erythorbate; T3: chicken nuggets added of defatted rice bran without soy protein and sodium erythorbate.

\section{Physico-chemical parameters}

Moisture, ash, lipids, and crude protein were determined according to the Association of Official Analytical Chemists [AOAC] (2005). Carbohydrate values were calculated by difference: 100 - (\% moisture $+\%$ ash $+\%$ protein $+\%$ lipids). Physicochemical analyses were performed in duplicate. Water activity $\left(\mathrm{a}_{\mathrm{w}}\right)$ was determined in triplicate at $25^{\circ} \mathrm{C}$ using a Decagon water activity meter (DCG-40530 model, WA, USA). The nuggets samples $\mathrm{pH}$ was measured in triplicate using a $\mathrm{pH}$ meter ( $\mathrm{pH} 21$, Hanna $^{\circledR}$, Romania) using $10 \mathrm{~g}$ of sample homogenized with $50 \mathrm{~mL}$ distilled water (International Standards Organization [ISO], 1999).

Color measurements were performed inside the nuggets at three different points using a Konica Minolta colorimeter (CR400 model, NJ, USA) with an integrating sphere and $45^{\circ}$ viewing angle (d/45 lighting and D illuminating) (Seganfredo, Rodrigues, Kalschne, Sarmento, \& Canan, 2016). Lightness $\left(\mathrm{L}^{*}\right)$, green-red chromaticity $\left(\mathrm{a}^{*}\right)$ and blue-yellow chromaticity (b*) were measured according to CIELAB system.

For shear force evaluation, the nuggets were cut into $1.5 \times 1.0 \times 2 \mathrm{~cm}$ (height $\mathrm{x}$ width $\mathrm{x}$ length) pieces. Analyses were performed using a texture analyzer (TA.HD plus, Stable Micro Systems, UK) fitted with a Warner Bratzler probe and $5 \mathrm{~g}$ charge cell at a $5.0 \mathrm{~mm} \mathrm{~s}^{-1}$ speed and a $20 \mathrm{~mm}$ distance with a $0.001 \mathrm{~mm}$ resolution. The results of the minimum force required for cutting were given in Newton $(\mathrm{N})$ and determined by five repetitions.

\section{Lipid stability}

The chicken nuggets were thawed $\left(4 \pm 1{ }^{\circ} \mathrm{C}\right.$ for $3 \mathrm{~h})$ before the lipid oxidation analysis performed at days 0 (24 h after preparation), 30, and 60 by thiobarbituric acid reactive substances (TBARS). The samples were analyzed in duplicate using Tarladgis, Pearson and Dugan method (1964), modified by Crackel, Gray, Booren and Buclely (1988). 


\section{Microbiological parameters}

The nuggets were evaluated in terms of Salmonella ssp., coagulase-positive Staphylococcus and coliforms at $45^{\circ} \mathrm{C}$ for $24 \mathrm{~h}$ in duplicate (Silva et al., 2010).

\section{Sensory analysis}

Sensory analysis was carried out for treatments T1 and T3 after 60 days of storage $\left(-20 \pm 1{ }^{\circ} \mathrm{C}\right)$. Sample T2 (without antioxidant) was unsuitable for sensory analysis due to its high TBARS value and altered smell (rancid taste and aroma) after cooking. Notably, cooked meats are known to develop a fast and intense flavor deterioration after cold storage, usually described as warmed-overflavor (WOF) (Carvalho, Shimokomaki, \& Este 2017). An experimental randomized block design considering the samples and the panelists as a source of variation was used. Sensory analysis was performed according to ethical guidelines (CAAE 733.002/2014), under artificial white light using individual booths. A 50-person panel (consumers) randomly selected consisting of academics, teachers and university employees, aged from 19 to 50 years old, male and female, evaluated the samples.

The 9-point hedonic scale ( $9=$ like extremely; $5=$ not like/not dislike; 1 = dislike extremely) was employed to evaluate color, aroma, flavor, texture, and overall impression. The nuggets were thawed and baked until reaching $80 \pm 1{ }^{\circ} \mathrm{C}$ minimum internal temperature (10537-13368 model Hot Grill, Fisher, Brazil), cooled to approximately $45{ }^{\circ} \mathrm{C}$ and served. The samples were coded with random threedigit numbers presented monadically and randomly balanced order.

The acceptability index (AI) was calculated according to the equation (Teixeira, Meinert, \& Barbetta, 1987): AI = average grade/highest score*100.

\section{Statistical analysis}

Physico-chemical data were evaluated by a oneway ANOVA and the acceptance data evaluated by the main effects ANOVA and Tukey test (at a 5\% significance level) using the STATISTICA version 8.0 software (Statsoft Inc., Tulsa, OK, USA).

\section{Results and Discussion}

\section{Physico-chemical parameters}

All chicken nuggets formulations followed the total carbohydrates content (maximum 30 g 100 $\mathrm{g}^{-1}$ ) and protein (minimum $10 \mathrm{~g} 100 \mathrm{~g}^{-1}$ ) (Instrução Normativa n. 6, 2001). Sample T3 (with rice bran) presented moisture, protein, lipids, and carbohydrate content $(p>0.05)$ similar to T1 (with soy protein and sodium erythorbate). The ash content was higher for $\mathrm{T} 3$, probably due to the high ash content form the

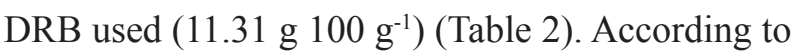
Lacerda et al. (2010), rice bran could be considered a mineral source with contents between 7.76 and

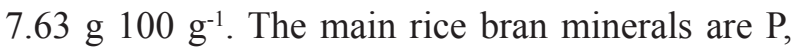
$\mathrm{K}$ and $\mathrm{Mg}$ and, to a lesser extent, $\mathrm{Ca}, \mathrm{Mn}, \mathrm{Fe}$ and $\mathrm{Zn}$. For T2, a higher moisture value $\left(5 \mathrm{~g} 100 \mathrm{~g}^{-1}\right)$

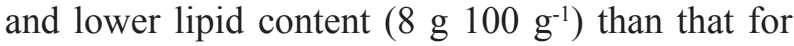
T1 was observed. This has probably occurred due to raw material composition, as previously reported by Seganfredo et al. (2016). However, this variation, although statistically significant $(\mathrm{p}<$ $0.05)$, was lower than the tolerated one (20 g 100 $\mathrm{g}^{-1}$ ) (Resolução RDC n. 360, 2003).

The $\mathrm{pH}$ values were similar for all chicken nuggets samples $(p>0.05)$, varying between 6.55 and 6.67 (Table 2). Water activity for T3 was higher than that to $\mathrm{T} 1$ and $\mathrm{T} 2(\mathrm{p}<0.05)$, varying from 0.93 to 0.97 . The highest water activity of $\mathrm{T} 3$ was probably due to soy protein absence, of which carbohydrates could bind water (Reid \& Fennema, 2010). 
Table 2

Results of physico-chemical parameters of chicken nuggets

\begin{tabular}{cccccccc}
\hline Sample & $\begin{array}{c}\text { Moisture } \\
(\%)\end{array}$ & $\begin{array}{c}\text { Protein } \\
(\%)\end{array}$ & $\begin{array}{c}\text { Ash } \\
(\%)\end{array}$ & $\begin{array}{c}\text { Lipid } \\
(\%)\end{array}$ & $\begin{array}{c}\text { Carbohydrate } \\
(\%)\end{array}$ & $\begin{array}{c}\text { Water } \\
\text { activity }\end{array}$ & pH \\
\hline T1 & $54.56 \pm 0.48^{\mathrm{b}}$ & $11.03 \pm 0.14^{\mathrm{a}}$ & $2.58 \pm 0.24^{\mathrm{b}}$ & $18.17 \pm 0.04^{\mathrm{a}}$ & $13.66 \pm 0.63$ & $0.93 \pm 0.01^{\mathrm{b}}$ & $6.62 \pm 0.12^{\mathrm{a}}$ \\
$\mathrm{T} 2$ & $57.28 \pm 0.51^{\mathrm{a}}$ & $10.00 \pm 1.23^{\mathrm{a}}$ & $2.76 \pm 0.18^{\mathrm{b}}$ & $16.77 \pm 0.04^{\mathrm{b}}$ & $13.18 \pm 1.32$ & $0.96 \pm 0.02^{\mathrm{ab}}$ & $6.67 \pm 0.07^{\mathrm{a}}$ \\
$\mathrm{T} 3$ & $54.03 \pm 0.07^{\mathrm{b}}$ & $10.67 \pm 1.09^{\mathrm{a}}$ & $3.32 \pm 0.10^{\mathrm{a}}$ & $18.28 \pm 0.11^{\mathrm{a}}$ & $14.52 \pm 0.83$ & $0.97 \pm 0.01^{\mathrm{a}}$ & $6.55 \pm 0.05^{\mathrm{a}}$ \\
\hline DRB & $11.09 \pm 0.12$ & $14.89 \pm 0.29$ & $11.31 \pm 0.64$ & $1.67 \pm 0.04$ & $61.03 \pm 0.53$ & - & - \\
\hline
\end{tabular}

T1: chicken nuggets added of soy protein and sodium erythorbate; T2: chicken nuggets added of soy protein without sodium erythorbate; T3: chicken nuggets added of defatted rice bran without soy protein and sodium erythorbate; DRB: defatted rice bran. Means \pm standard deviation ( $\mathrm{n}=2$ for all, except water activity and $\mathrm{pH} \mathrm{n}=3$ ); different superscript letters on the same row have significant difference by Tukey test $(\mathrm{p}<0.05)$.

DRB addition improved the darkness of T3 ( $\mathrm{L}^{*}$ $=59.32)(\mathrm{p}<0.05)$ compared to $\mathrm{T} 1$ and $\mathrm{T} 2$. The $\mathrm{a}^{*}$ value (green-red component) was lower for $\mathrm{T} 1$ and statistically different from $\mathrm{T} 2$ and $\mathrm{T} 3(\mathrm{p}<0.05)$. The $\mathrm{b}^{*}$ value (yellow-blue component) and shear force were similar among all samples $(p>0.05)$ (Table 3 ).

Table 3

Results of color parameters and texture of chicken nuggets

\begin{tabular}{ccccc}
\hline Sample & $\mathrm{L}^{*}$ & $\mathrm{a}^{*}$ & $\mathrm{~b}^{*}$ & Shear force $(\mathrm{N})$ \\
\hline T1 & $63.36 \pm 1.28^{\mathrm{a}}$ & $-1.5 \pm 0.48^{\mathrm{b}}$ & $16.05 \pm 0.57^{\mathrm{a}}$ & $9.32 \pm 0.46^{\mathrm{a}}$ \\
T2 & $62.47 \pm 0.25^{\mathrm{a}}$ & $-0.25 \pm 0.29^{\mathrm{a}}$ & $15.84 \pm 0.80^{\mathrm{a}}$ & $8.64 \pm 0.44^{\mathrm{ab}}$ \\
T3 & $59.32 \pm 2.28^{\mathrm{b}}$ & $0.22 \pm 0.23^{\mathrm{a}}$ & $15.51 \pm 0.74^{\mathrm{a}}$ & $8.12 \pm 0.29^{\mathrm{b}}$ \\
\hline
\end{tabular}

T1: chicken nuggets added of soy protein and sodium erythorbate; T2: chicken nuggets added of soy protein without sodium erythorbate; T3: chicken nuggets added of defatted rice bran without soy protein and sodium erythorbate.

Means \pm standard deviation $(n=3)$; different superscript letters on the same row have significant difference by Tukey test $(\mathrm{p}<$ $0.05)$.

\section{Lipid stability}

At day 0 , no difference was observed among the chicken nuggets samples in terms of TBARS (Table 4). However, after 30 and 60 storage days, the lipid stability for T1 and T3 samples was greater than that for the $\mathrm{T} 2$ one $(\mathrm{p}<0.05)$, due to the absence of antioxidants in T2. Moreover, T3 (with DRB as an antioxidant) and $\mathrm{T} 1$ samples exhibited a similar value for TBARS $(p<0.05)$ on all evaluated storage days, and a lower value compared to $\mathrm{T} 2$ at 30 and 60 storage days $(\mathrm{p}<0.05)$. The malonaldehyde (MDA) results can be correlated with sensory characteristics of rancidity flavor and aroma; this can be observed in sample T2, which had a MDA content above the threshold $\left(0.50 \mathrm{mg} \mathrm{MDA} \mathrm{kg}{ }^{-1}\right)$ and negative sensory characteristics (Andrade, Ribeiro-Santos, Guerra, \& Sanches-Silva, 2019). Thus, the DRB showed suitability for lipid stability improvement, comparable to sodium erythorbate. Moreover, T3 presented greater lipid stability along the 60 days evaluated, taking into account that no difference on MDA content was observed.

Almeida, Villanueva, Gonçalves and ContrerasCastillo (2015) reported a greater value for TBARS, ranging from 0.20 and $0.34 \mathrm{mg}$ MDA $\mathrm{kg}^{-1} 48 \mathrm{~h}$ after chicken nuggets elaboration. The 
MDA content control - the major lipid oxidation byproduct- is of utmost importance in foods since it causes unpleasant flavors, discoloration, cytotoxic, carcinogenic and mutagenic effects, cholesterol oxidation and nutritional value loss due to vitamins and essential fatty acids destruction (Estévez \& Lorenzo 2019).
The interest in natural food additives by consumers has reinforced the need for effective natural antioxidants development as an alternative to prevent meat products from deteriorating during processing and storage. Rice bran is a rich source of antioxidants (Canan et al., 2012) and it efficiently prevents lipid oxidation in meat products, as described in the present manuscript.

Table 4

Results of lipid oxidation (TBARS, mg malonaldehyde $\mathrm{kg}^{-1}$ ) on chicken nuggets

\begin{tabular}{cccc}
\hline Sample & Day 0 & Day 30 & Day 60 \\
\hline T1 & $0.28 \pm 0.01^{\mathrm{aA}}$ & $0.16 \pm 0.03^{\mathrm{bB}}$ & $0.17 \pm 0.01^{\mathrm{bB}}$ \\
$\mathrm{T} 2$ & $0.22 \pm 0.03^{\mathrm{aB}}$ & $0.36 \pm 0.06^{\mathrm{aAB}}$ & $0.51 \pm 0.02^{\mathrm{aA}}$ \\
$\mathrm{T} 3$ & $0.28 \pm 0.08^{\mathrm{aA}}$ & $0.13 \pm 0.04^{\mathrm{bA}}$ & $0.23 \pm 0.03^{\mathrm{bA}}$ \\
\hline
\end{tabular}

T1: chicken nuggets added of soy protein and sodium erythorbate; T2: chicken nuggets added of soy protein without sodium erythorbate; T3: chicken nuggets added of defatted rice bran without soy protein and sodium erythorbate.

Means \pm standard deviation $(n=2)$; different superscript lowercase letters on the same row or different superscript uppercase in the same line have significant difference by Tukey test $(\mathrm{p}<0.05)$.

\section{Microbiological parameters}

The microbiological parameters results are seen in Table 5. Salmonella spp. was not detected on the samples, while the coagulase-positive Staphylococcus count was $<10^{2} \mathrm{CFU} \mathrm{g} \mathrm{g}^{-1}$, and the
Coliforms at $45{ }^{\circ} \mathrm{C}$ were $<3$ MPN g ${ }^{-1}$. Similarly, Almeida et al. (2015) reported an expected microbiological quality for chicken nuggets (Resolução RDC n. 12, 2001).

Table 5

Results of microbiological parameters of chicken nuggets

\begin{tabular}{cccc}
\hline Sample & $\begin{array}{c}\text { Salmonella spp. } \\
\text { (in 25 g) }\end{array}$ & $\begin{array}{c}\text { Coagulase-positive } \\
\text { Staphylococcus }\left(\mathrm{CFU} \mathrm{g}{ }^{-1}\right)\end{array}$ & $\begin{array}{c}\text { Coliform at } 45^{\circ} \mathrm{C} \\
\left(\mathrm{MPN} \mathrm{g}^{-1}\right)\end{array}$ \\
\hline $\mathrm{T} 1$ & Absence & $<10^{2}$ & $<3$ \\
$\mathrm{~T} 2$ & Absence & $<10^{2}$ & $<3$ \\
$\mathrm{~T} 3$ & Absence & $<10^{2}$ & $<3$ \\
Limit* & Absence & $5 \times 10^{2}$ & $10^{2}$ \\
\hline
\end{tabular}

T1: chicken nuggets added of soy protein and sodium erythorbate; T2: chicken nuggets added of soy protein without sodium erythorbate; T3: chicken nuggets added of defatted rice bran without soy protein and sodium erythorbate; CFU $\mathrm{g}^{-1}$ : colony-forming unit per gram of sample; MNP g-1. most probable number per gram of sample.

* Resolução RDC n. 12, 2001. 


\section{Sensory acceptance}

The sensory acceptance values for T1 and T3 samples are presented in Table 6. No differences were observed between samples for all attributes $(\mathrm{p}>0.05)$. The acceptability index varied between 72.4 and $82.0 \%$ for attributes evaluated, and were higher than $70 \%$ - suggested as the minimum for a product to be sensorially accepted (Teixeira et al., 1987). Thus, the replacement of soy protein and sodium erythorbate by DRB can be performed in chicken nuggets, reinforcing the sensory acceptance of product after 60 days of storage. In the same context, Huang, Shiau, Liu, Chu and Hwang (2005) investigated the rice bran addition in Kung-wan (an emulsified pork meatball). The sensory acceptance of scores of flavor, texture, and overall impression of meatballs with up to $10 \%$ rice bran showed no difference from control meatballs (without rice bran).

Table 6

Results of sensory acceptance of chicken nuggets

\begin{tabular}{cccccc}
\hline Sample & Color & Aroma & Flavor & Texture & Overall impression \\
\hline T1 & $6.68 \pm 1.28^{\mathrm{a}}$ & $7.38 \pm 1.37^{\mathrm{a}}$ & $7.02 \pm 1.35^{\mathrm{a}}$ & $7.04 \pm 1.55^{\mathrm{a}}$ & $7.12 \pm 1.24^{\mathrm{a}}$ \\
T3 & $6.52 \pm 1.72^{\mathrm{a}}$ & $7.10 \pm 1.63^{\mathrm{a}}$ & $6.62 \pm 1.72^{\mathrm{a}}$ & $6.96 \pm 1.73^{\mathrm{a}}$ & $6.98 \pm 1.36^{\mathrm{a}}$ \\
\hline T1 & \multicolumn{7}{c}{ Acceptability index (\%) } \\
T3 & 74.2 & 82.0 & 78.0 & 78.2 & 79.1 \\
\hline
\end{tabular}

T1: chicken nuggets added of soy protein and sodium erythorbate; T3: chicken nuggets added of defatted rice bran without soy protein and sodium erythorbate. Hedonic scale: $9=$ extremely like; $5=$ not like/not dislike; 1 = extremely dislike.

Means \pm standard deviation $(n=50)$; different superscript letters on the same row have significant difference by Tukey test $(\mathrm{p}<$ $0.05)$.

\section{Conclusions}

The replacement of soy protein by DRB showed no influence on chicken nuggets texture, evaluated by instrumental and sensory analysis. Additionally, the DRB presented a suitable antioxidant potential, comparable to sodium erythorbate. The centesimal composition and microbiological parameters were either not influenced, or positively influenced by DRB addition. The total replacement of soy protein and sodium erythorbate by DRB ensured the sensory acceptance in terms of color, aroma, flavor, texture, and overall impression, with acceptability index greater than $72.4 \%$. Thus, DRB is a natural ingredient that meets consumers demand for healthy meat products. Moreover, DRB addition to meat products increases the value for a secondary byproduct from rice-processing plants.

\section{Acknowledgements}

The authors acknowledge Irgovel by the rice bran donation. This study was financed in part by the Coordenação de Aperfeiçoamento de Pessoal de Nível Superior - Brasil (CAPES) - Finance Code 001, Fundação Araucária and UTFPR.

\section{References}

Akihisa, T., Yasukawa, K., Yamaura, M., Ukiya, M., Kimura, Y., Shimizu, N., \& Arai, K. (2000). Triterpene alcohol and sterol ferulates from rice bran and their anti-inflammatory effects. Journal of Agricultural and Food Chemistry, 48(6), 2313-2319. doi: 10.1021/jf000135o

Almeida, M. A., Villanueva, N. D. M., Gonçalves, J. R., \& Contreras-Castillo, C. J. (2015). Quality attributes and consumer acceptance of new ready-to-eat frozen 
restructured chicken. Journal of Food Science and Technology, 52(5), 2869-2877. doi: 10.1007/s13197014-1351-5

Andrade, M. A., Ribeiro-Santos, R., Guerra, M., \& Sanches-Silva, A. (2019). Evaluation of the oxidative status of salami packaged with an active whey protein film. Foods, 8(387), 1-15. doi: 10.3390/ foods 8090387

Association of Official Analytical Chemists (2005). Official methods of analysis of the Association Analytical Chemists (18nd ed.). Gaithersburg: AOAC.

Basanta, M. F., Rizzo, S. A., Szerman, N., Vaudagna, S. R., Descalzo, A. M., Gerschenson, L. N.,... Rojas, A. M. (2018). Plum (Prunus Salicina) peel and pulp microparticles as natural antioxidant additives in breast chicken patties. Food Research International, 106, 1086-1094. doi: 10.1016/j.foodres.2017.12.011

Canan, C., Delaroza, F., Casagrande, R., Baracat, M. M., Shimokomaki, M., \& Ida, E. I. (2012). Antioxidant capacity of phytic acid purified from rice bran. Acta Scientiarum, 34(4), 457-463. doi: 10.4025/ actascitechnol.v34i4.16358

Carvalho, R., Shimokomaki, M., \& Estévez, M. (2017). Poultry meat color and oxidation. In M. Petracci, \& C. Berri (Eds.,), Poultry quality evaluation (pp. 133157). Oxford: Woodhead Publishing.

Chan, K. W., Khong, N. M. H., Iqbal, S., \& Ismail, M. (2013). Isolation and antioxidative properties of phenolics-saponins rich fraction from defatted rice bran. Journal of Cereal Science, 57(3), 480-485. doi: 10.1016/j.jcs.2013.02.002

Chanput, W., Theerakulkait, C., \& Nakai, S. (2009). Antioxidative properties of partially purified barley hordein, rice bran protein fractions and their hydrolysates. Journal of Cereal Science, 49(3), 422428. doi: 10.1016/j.jcs.2009.02.001

Chotimarkorn, C., Benjakul, S., \& Silalai, N. (2008). Antioxidative effects of rice bran extracts on refined tuna oil during storage. Food Research International, 41(6), 616-622. doi: 10.1016/j.foodres. 2008.04.002

Chrastil, J. (1992). Correlations between the physicochemical and functional properties of rice. Journal of Agricultural and Food Chemistry, 40(9), 1683-1689. doi: 10.1021/jf00021a040

Crackel, R. L., Gray, J. I., Booren, A. M., \& Buckely, D. J. (1988). Effect of antioxidants on lipid stability in restructured beef steaks. Journal of Food Science, 53(2), 656-657. doi: 10.1111/j.1365-2621.1988. tb07780.x
Ebisawa, M., Ito, K., Fujisawa, T. (2017). Japanese guidelines for food allergy 2017. Allergology International, 66(2), 248-64. doi: 10.1016/j. alit.2017.02.001

Estévez, M., \& Lorenzo, J. M. (2019). Impact of antioxidants on oxidized proteins and lipids in processed meat. Encyclopedia of Food Chemistry, (1), 600-608. doi: 10.1016/b978-0-08-100596-5.21501-1

Goufo, P., \& Trindade, H. (2014). Rice antioxidants: phenolic acids, flavonoids, anthocyanins, proanthocyanidins, tocopherols, tocotrienols, c-oryzanol, and phytic acid. Food Science \& Nutrition, 2(2), 75-104. doi: 10.1002/fsn3.86

Gul, K., Yousuf, B., Singh, A. K., Preeti, S., \& Wani, A. A. (2015). Rice bran: nutritional values and its emerging potential for development of functional food - A review. Bioactive Carbohydrates and Dietary Fibre, 6(1), 24-30. doi: 10.1016/j.bcdf.2015.06.002

Han, S. W., Chee, K. M., \& Cho, S. J. (2015). Nutritional quality of rice bran protein in comparison to animal and vegetable protein. Food Chemistry, 172(1), 766769. doi: 10.1016/j.foodchem.2014.09.127

Huang, S. C., Shiau, C. Y., Liu, T. E., Chu, C. L., \& Hwang, D. F. (2005). Effects of rice bran on sensory and physico-chemical properties of emulsified pork meatballs. Meat Science, 70(4), 613-619. doi: 10.1016/j.meatsci.2005.02.009

Instrução Normativa n. 6, de 15 de fevereiro de 2001. Dispõe sobre o Regulamento técnico de identidade e qualidade de empanados. Diário Oficial da União, Brasília.

International Standards Organization (1999). Meat and meat products - measurement of $\mathrm{pH}$ (Reference method ISO 2917). Geneva: The International Organization for Standardization.

Jariwalla, R. J. (2001). Rice-bran products: phytonutrients with potential applications in preventive and clinical medicine. Drugs Under Experimental and Clinical Research, 27(1), 17-26.

Lacerda, D. B. C. L., Soares, M. S., Jr., Bassinello, P. Z., Castro, M. V. L., Silva-Lobo, V. L., Campos, M. R. H., \& Siqueira, B. S. (2010). Qualidade de farelos de arroz cru, extrusado e parboilizado. Pesquisa Agropecuária Tropical, 40(4), 521-530. doi: $10.5216 /$ pat.v40i4.7266

Nandi I., \& Ghosh, M. (2015). Studies on functional and antioxidant property of dietary fibre extracted from defatted sesame husk, rice bran and flaxseed. Bioactive Carbohydrates and Dietary Fibre, 5, 129136. doi: 10.1016/j.bcdf.2015.03.001 
Olivo, R. (2006). Alterações oxidativas em produtos cárneos. In M. Shimokomaki, R. Olivo, N. N. Terra, \& B. D. G. M. Franco (Eds.), Atualidades em ciência e tecnologia de carnes (pp. 155-162). São Paulo: Varela.

Pestana, V. R., Mendonça, C. R. B., \& Zambiázi, R. C. (2008). Farelo de arroz: características, benefícios à saúde e aplicações. Boletim CEPPA, 26(1), 29-40. doi: 10.5380/cep.v26i1.11789

Piccolo, F., Vollano, L., Base, G., Girasole, M., Smaldone, G., \& Cortesi, M. L. (2016). Soybean and lactose in meat products and preparations sampled at retail. Italian Journal of Food Safety, 5(3), 161-64. doi: $10.4081 /$ ijfs. 2016.5780

Reid, D. S., \& Fennema, O. R. (2010). Água e gelo. In S. Damodaram, K. L. Parkin, \& O. R. Fennema (Eds.), Química de alimentos de fennema (4a ed., pp. 2674). São Paulo: Artmed.

Resolução RDC n. 12, de 2 de janeiro de 2001. Dispões sobre o Regulamento Técnico Sobre Padrões de Microbiológicos para Alimentos. Diário Oficial da União, Brasília.

Resolução RDC n. 360, de 23 de dezembro de 2003. Aprova Regulamento técnico sobre rotulagem nutricional de alimentos embalados, tornando obrigatória a rotulagem nutricional. Diário Oficial da União, Brasília.

Seganfredo, D., Rodrigues, S., Kalschne, D. L., Sarmento, C. M. P., \& Canan, C. (2016). Partial substitution of sodium chloride in Toscana sausages and the effect on product characteristics. Semina: Ciências Agrárias, 37(3), 1285-1294. doi: 10.5433/1679-0359.2016v37 n3p 1285

Shimokomaki, M. (2006). Atualidades em ciência e tecnologia de carnes. São Paulo: Varela.

Shoji, Y., Mita, T., Isemura, M., Mega, T., Hase, S., Isemura, S., \& Aoyagi, Y. A. (2001). Fibronectinbinding protein from rice bran with cell adhesion activity for animal tumor cells. Bioscience, Biotechnology, and Biochemistry, 65(5), 1181-1186. doi: $10.1271 / \mathrm{bbb} .65 .1181$

Silva, C. R., Oliveira, J. E. D., Souza, R. A., \& Silva, H. C. (2005). Effect of a rice bran fiber diet on serum glucose levels of diabetic patients in Brazil. Archivos Latinoamericanos de Nutrición, 55(1), 23-27.
Silva, N., Junqueira, V. C. A., Silveira, N. F. A., Taniwaki, M. H., Santos, R. F. S., Gomes, R. A. R., \& Okazaki, M. M. (2010). Manual de métodos de análises microbiológica de alimentos e água. São Paulo: Varela.

Takeshita, M., Nakamura, S., Makita, F., Ohwada, S., Miyamoto, Y., \& Morishita, Y. (1992). Antitumor effect of RBS (rice bran saccharide) on ENNGinduced carcinogenesis. Biotherapy, 4(2), 139-145. doi: 10.1007/BF02171758

Tarladgis, B. G., Pearson, A. M., \& Dugan, L. R. (1964). Chemistry of the 2-thiobarbituric acid test for determination of oxidative rancidity in foods. II. Formation of the TBA-malonaldehyde complex without acid-heat treatment. Journal of the Science of Food and Agriculture, 15(9), 602-607. doi: 10.1002/ jsfa.2740150904

Teixeira, E., Meinert, E. M., \& Barbetta, P. A. (1987). Análise sensorial de alimentos. Florianópolis: UFSC.

Thanonkaewa, A., Wongyai, S., Mcclements, D. J., \& Decker, E. A. (2012). Effect of stabilization of rice bran by domestic heating on mechanical extraction yield, quality, and antioxidant properties of coldpressed rice bran oil (Oryza saltiva L.). Food Science and Technology, 48(2), 231-236. doi: 10.1016/j. lwt.2012.03.018

Tzianabos, A. O. (2000). Polysaccharide immunomodulators as therapeutic agents: structural aspects and biologic function. Clinical Microbiology Review, 13(4), 523-533.

Wang, M., Hettiarachchy, N. S., Qi, M., Burks, W., \& Siebenmogen, T. (1999). Preparation and functional properties of rice bran protein isolate. Journal of Agricultural and Food Chemistry, 47(2), 411-416. doi: 10.1021/jf9806964

Zhang, H. J., Zhang, H., Wang, L., \& Guo, X. N. (2012). Preparation and functional properties of rice bran proteins from heat-stabilized defatted rice bran. Food Research International, 47(2), 359-363. doi: 10.1016/j.foodres.2011.08.014

Zheng, Y., Nisi G., Wu, J., \& Yin, B. (2019). Rice bran protein: extraction, nutraceutical properties, and potential applications. In L.-Z. Cheong, \& X. Xu (Eds.), Rice bran and rice bran oil (pp. 271-293). New York: Academic Press. 